\title{
Recent Advances in Copper Catalyzed Alcohol Oxidation in Homogeneous Medium
}

\author{
Telma F. S. Silva *(i) and Luísa M. D. R. S. Martins* *(]) \\ Centro de Química Estrutural, Instituto Superior Técnico, Universidade de Lisboa, Av. Rovisco Pais, \\ 1049-001 Lisboa, Portugal \\ * Correspondence: telma.silverio.silva@gmail.com (T.F.S.S.); luisammartins@tecnico.ulisboa.pt (L.M.D.R.S.M.); \\ Tel.: +351-218-419-389 (L.M.D.R.S.M.)
}

Received: 31 December 2019; Accepted: 6 February 2020; Published: 9 February 2020

\begin{abstract}
The development of sustainable processes and products through innovative catalytic materials and procedures that allow a better use of resources is undoubtedly one of the most significant issues facing researchers nowadays. Environmental and economically advanced catalytic processes for selective oxidation of alcohols are currently focused on designing new catalysts able to activate green oxidants (dioxygen or peroxides) and applying unconventional conditions of sustainable significance, like the use of microwave irradiation as an alternative energy source. This short review aims to provide an overview of the recently (2015-2020) discovered homogeneous aerobic and peroxidative oxidations of primary and secondary alcohols catalyzed by copper complexes, highlighting new catalysts with potential application in sustainable organic synthesis, with significance in academia and industry.
\end{abstract}

Keywords: copper; complexes; homogeneous catalysis; peroxidative; aerobic; oxidation of alcohols

\section{Introduction}

In organic synthesis, the oxidation of primary and secondary alcohols to the corresponding carbonyl compounds, aldehydes (or carboxylic acids) and ketones, respectively, plays a central role due to the wide use of these commodities as precursors and intermediates for fine chemistry (mainly drugs, vitamins and fragrances) [1-3].

Classic oxidation methods use stoichiometric quantities of inorganic oxidants, such as manganese dioxide, chromium(VI) or the Swern or Dess-Martin reagents [4], which are often toxic and generate considerable amounts of by-products. Moreover, many of the early found catalytic systems suffer from high reagent cost, instability, employment of hazardous metals or oxidants, harsh reaction conditions, operational complexity, functional group incompatibility or production of non-processable wastes.

Fortunately, the state-of-the-art in alcohol oxidation research is nowadays by far better. Many catalytic methods that can be used to oxidize alcohols by using peroxides or dioxygen as alternative oxidants are now known, and the implementation of a transition metal-based catalyst in combination with them represents emerging sustainable alternatives to the traditional procedures $[1,5]$ (Scheme 1). Typically, selective peroxidative oxidations of alcohols involve early transition elements in high-oxidation states and peroxometal complexes as the active oxidants. Aerobic oxidations, in contrast, involve oxidative dehydrogenation that is generally catalyzed by late-transition elements.

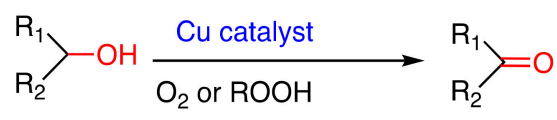

Scheme 1. Selective oxidation of primary $\left(R_{1}=H, R_{2} \neq H\right)$ and secondary $\left(R_{1}, R_{2} \neq H\right)$ alcohols. 
The development of efficient oxidation systems by using economic and less hazardous catalysts, oxidants and solvents, under mild conditions, has become a relevant aim for catalytic-processes designing, and $\mathrm{Cu}$-containing compounds are of a high potential interest among transition metal catalysts. In fact, copper is cheap and widespread in nature (attractive from the industrial viewpoint) and is present in the active sites of many metalloproteins, particularly in enzymes [6,7] (e.g., particulate methane monooxygenase, galactose oxidase, hemocyanin, cytochrome c, catechol oxidase, laccases or superoxide dismutase). Mononuclear copper complexes, in combination with 2,2,6,6-tetramethylpiperidine-1-oxyl radical (TEMPO), have emerged as one of the most effective catalysts for selective alcohol oxidation, and these catalytic systems are frequently considered the biomimetic functional model of the galactose oxidase enzyme [8]. The efficiency of the latter has led to extensive research to mimic the active sites of this enzyme, leading to a variety of $\mathrm{Cu} / \mathrm{TEMPO}$ catalytic systems being reported over the years. Thus, copper has drawn particular attention in catalyst design, and exciting research in the realm of coordination chemistry has been reported [8,9].

Nevertheless, numerous challenges remain in the progress of copper-catalyzed aerobic or peroxidative alcohol oxidations with high catalytic activity and selectivity as alternatives for conventional stoichiometric oxidation methods. Since a myriad of procedures are available for the oxidation of alcohols, practicality plays an important role in any new method. This includes mild reaction conditions, low pressures of $\mathrm{O}_{2}$ (especially in flammable organic solvents) or low amounts of peroxide, low catalyst loading and low temperatures (preferably room temperature), and the avoidance of costly/toxic additives (co-catalyst, promotor, etc.). Other key challenges are functional group tolerance and the ability to chemoselectively oxidize the alcohol in the presence of other groups susceptible to oxidation.

In this minireview, the most recent advances (2015-2020 period) in the peroxidative or aerobic oxidation of primary and secondary alcohols, using copper catalysts in homogeneous medium, are addressed.

\section{Peroxidative Oxidation of Alcohols}

\subsection{Oxidation with Hydrogen Peroxide}

Peroxidative oxidations of alcohols are typical model reactions due to their importance and generality; inexpensive, hydrogen peroxide or tert-butyl hydroperoxide oxidants, and simple procedures are usually involved. As peroxides can be commercially obtained in aqueous solutions, attempts to improve the sustainability of alcohol oxidations address the use of water as solvent. Therefore, recently, new water-soluble copper complexes have been synthesized, and their ability to act as catalysts for the oxidation of alcohols in aqueous medium have been evaluated. Hydrogen peroxide, the most environmentally friend peroxide, was always the selected oxidant. Indeed, in the environment, hydrogen peroxide, which does not evaporate from water or adsorb to soil, is quickly decomposed by biological and/or chemical processes, to form water and oxygen.

In 2017, Kani and coworkers reported the use of the water-soluble mononuclear $\mathrm{Cu}$ (II) complex $\left[\mathrm{Cu}\left(\mathrm{OOCC}\left(\mathrm{C}_{6} \mathrm{H}_{5}\right)_{3}\right)\right.$ (bipy) $\left.\left(\mathrm{H}_{2} \mathrm{O}\right)\right]\left[\mathrm{ClO}_{4}\right]\left(\mathrm{CH}_{3} \mathrm{OH}\right)(\mathbf{1}$, bipy $=2$-2'-bipyridyl, Figure 1$)$ as catalyst precursor for the oxidation of primary (benzyl alcohol or 1-heptanol) and secondary (1-phenylethanol, 3-pentanol or 2-octanol) alcohols with $\mathrm{H}_{2} \mathrm{O}_{2}$ in water (Table 1). Complex 1 exhibited high catalytic activity toward the oxidation of benzyl alcohol to benzaldehyde as the only product ( $97 \%$ yield after $6 \mathrm{~h}$, entry 1, Table 1) [10] in low load ( $1 \mathrm{~mol} \%$ vs. substrate) and at a moderate temperature $\left(70{ }^{\circ} \mathrm{C}\right)$, whereas a more modest activity toward the production of acetophenone or 3-pentanone was observed for the same catalyst (e.g., $73 \%$ after $6 \mathrm{~h}$ and $100 \%$ yield of acetophenone after $24 \mathrm{~h}$; entries 4 and 5, Table 1). Later, the same researchers investigated [11] the catalytic activity of the new water-soluble $\mathrm{Cu}(\mathrm{II})$ complex bearing 4-bromobenzoate/2,2'-dipyridylamine $\left[\mathrm{Cu}\left(\mathrm{OOC}\left(\mathrm{C}_{6} \mathrm{H}_{5}\right) \mathrm{Br}\right)\left(\mathrm{C}_{10} \mathrm{H}_{9} \mathrm{~N}_{3}\right)\right]\left[\mathrm{ClO}_{4}\right]$ (2, Figure 1) for the oxidation of the above alcohols, using the same reaction conditions. Moreover, 2 also exhibited high selectivity toward benzaldehyde, but only $71 \%$ of benzyl alcohol conversion after 
6 h (entry 10, Table 1) was achieved. The observed behavior of 1 toward the oxidation of secondary alcohols was also found for $\mathbf{2}$. For example, complete conversion of 1-phenylethanol to acetophenone was reached only after $24 \mathrm{~h}$ (86\% after 6 h; entries 14 and 13, respectively, Table 1).

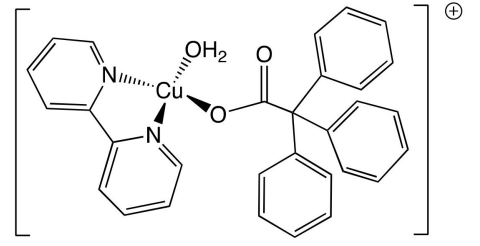

1

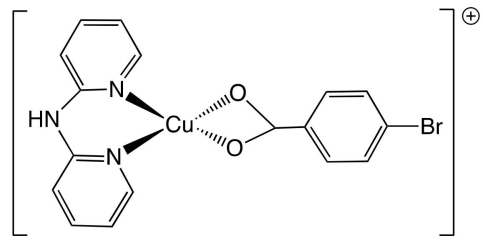

2

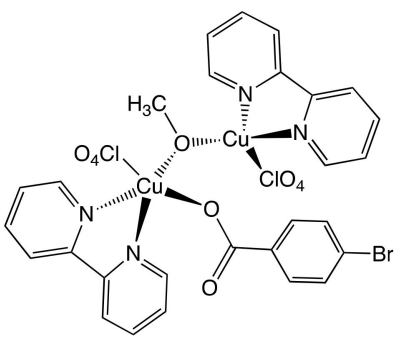

3

Figure 1. Mononuclear $\mathrm{Cu}(\mathrm{II})$ complexes $\left[\mathrm{Cu}\left(\mathrm{OOCC}\left(\mathrm{C}_{6} \mathrm{H}_{5}\right)_{3}\right)(\right.$ bipy $\left.)\left(\mathrm{H}_{2} \mathrm{O}\right)\right]\left[\mathrm{ClO}_{4}\right]\left(\mathrm{CH}_{3} \mathrm{OH}\right)(\mathbf{1})$, bipy = 2-2'-bipyridyl) and $\left[\mathrm{Cu}\left(\mathrm{OOC}\left(\mathrm{C}_{6} \mathrm{H}_{5}\right) \mathrm{Br}\right)\left(\mathrm{C}_{10} \mathrm{H}_{9} \mathrm{~N}_{3}\right)\right]\left[\mathrm{ClO}_{4}\right](2)$, and the di-nuclear $\mathrm{Cu}(\mathrm{II})$ complex $\left[\mathrm{Cu}_{2}\left(\mathrm{OOCC}_{6} \mathrm{H}_{4} \mathrm{Br}\right)\left(\mathrm{OCH}_{3}\right)(\text { bipy })_{2}\left(\mathrm{ClO}_{4}\right)_{2}\right](3)$.

Table 1. Catalytic performance of copper complexes 1-3 in the oxidation of alcohols by hydrogen peroxide in water.

\begin{tabular}{|c|c|c|c|c|c|c|}
\hline Entry & Catalyst & Time (h) & Substrate & Product & Yield (\%) & Ref. \\
\hline 1 & \multirow{9}{*}{$\mathbf{1}^{a}$} & 6 & benzyl alcohol & benzaldehyde & 97 & \multirow{9}{*}{ [10] } \\
\hline 2 & & 6 & cyclohexanol & cyclohexanone & 28 & \\
\hline 3 & & 24 & cyclohexanol & cyclohexanone & 52 & \\
\hline 4 & & 6 & 1-phenylethanol & acetophenone & 73 & \\
\hline 5 & & 24 & 1-phenylethanol & acetophenone & 100 & \\
\hline 6 & & 6 & 1-heptanol & 1-heptanone & 12 & \\
\hline 7 & & 24 & 2-octanol & 2-octanone & 11 & \\
\hline 8 & & 6 & 3-pentanol & 3-pentanone & 29 & \\
\hline 9 & & 24 & 3-pentanol & 3-pentanone & 100 & \\
\hline 10 & \multirow{6}{*}{$2^{b}$} & 6 & benzyl alcohol & benzaldehyde & 71 & \multirow{6}{*}{ [11] } \\
\hline 11 & & 6 & cyclohexanol & cyclohexanone & 29 & \\
\hline 12 & & 24 & cyclohexanol & cyclohexanone & 100 & \\
\hline 13 & & 6 & 1-phenylethanol & acetophenone & 86 & \\
\hline 14 & & 24 & 1-phenylethanol & acetophenone & 100 & \\
\hline 15 & & 24 & 2-octanol & 2-octanone & 11 & \\
\hline 16 & \multirow{5}{*}{$3^{c}$} & \multirow{5}{*}{6} & benzyl alcohol & benzaldehyde & 100 & \\
\hline 17 & & & cyclohexanol & cyclohexanone & 53 & \\
\hline 18 & & & 1-phenylethanol & acetophenone & 100 & \\
\hline 19 & & & 1-heptanol & 1-heptanone & 17 & \\
\hline 20 & & & cyclo-pentanol & cyclopentanone & 71 & [12] \\
\hline
\end{tabular}

${ }^{a}$ Alcohol $(0.76 \mathrm{mmol})$, catalyst $\left((0.1 \mathrm{~mol} \%\right.$ vs. alcohol $), \mathrm{H}_{2} \mathrm{O}_{2}(19.5 \mathrm{mmol}) .{ }^{b}$ Alcohol $(0.93 \mathrm{mmol})$, catalyst $(0.1 \mathrm{~mol} \%$ vs. alcohol), $\mathrm{H}_{2} \mathrm{O}_{2}(0.2 \mathrm{mmol}) .{ }^{c}$ Alcohol $(0.57 \mathrm{mmol})$, catalyst $\left(0.1 \mathrm{~mol} \%\right.$ vs. alcohol), $\mathrm{H}_{2} \mathrm{O}_{2}(19.5 \mathrm{mmol})$.

In 2018, Ünver et al. reported the homogenous oxidation of primary and secondary alcohols catalyzed by the related water-soluble di-nuclear $\mathrm{Cu}(\mathrm{II})$ complex $\left[\mathrm{Cu}_{2}\left(\mathrm{OOC}_{6} \mathrm{H}_{4} \mathrm{Br}\right)\left(\mathrm{OCH}_{3}\right)(\text { bipy })_{2}\left(\mathrm{ClO}_{4}\right)_{2}\right]$ (3, Figure 1), using $\mathrm{H}_{2} \mathrm{O}_{2}\left(30 \%\right.$ aq. solution) in water, under open air and at $70{ }^{\circ} \mathrm{C}$. The di-nuclear complex proved to be an active catalyst for producing the corresponding aldehydes or ketones. Thus, benzyl alcohol and 1-phenylethanol were quantitatively oxidized in $6 \mathrm{~h}$ (entries 16 and 18, respectively, Table 1), with concomitant high turnover number (TON) values [12].

Complex 3 was generally found to be more effective as a catalyst for benzylic and cyclic alcohols than for 1-heptanol as a primary aliphatic alcohol (compare entries 16-19 of Table 1). Moreover, the selectivity of this catalytic system was tested between a primary and a secondary alcohol, or between a cyclic alcohol and an aliphatic alcohol. For the oxidation of the mixture of benzyl alcohol 
and 1-phenylethanol, $16 \%$ of benzaldehyde was obtained, together with $62 \%$ of acetophenone. Hence, this catalytic system shows a preference to act on secondary alcohols. The oxidation of a mixture of a linear secondary alcohol (2-butanol) and a cyclic (cyclo-pentanol) one resulted in lower conversions for both, compared to yields of $100 \%$ and $71 \%$ for 2 -butanone and cyclopentanone obtained from experiments on a unique substrate. Thus, the experiments indicated that the competition between alcohols results in lower product yields compared to the pure substrates under the same conditions.

If an organic solvent must be used in an oxidation reaction, acetonitrile will be the chosen one by almost any researcher. In fact, acetonitrile is a medium-polarity solvent, miscible with water and a variety of organic solvents, able to dissolve a wide range of ionic, as well as nonpolar, compounds. More importantly, acetonitrile is usually inert under the oxidation conditions, even for the most drastic ones.

Thus, the catalytic potential of the recent mononuclear $\mathrm{Cu}(\mathrm{II})$ complex $\left[\mathrm{CuCl}_{2}\left(\mathrm{H}_{2} \mathrm{O}\right) \mathrm{L}\right](4$, $\mathrm{L}=$ 2,6-bis(5-tert-butyl-1H-pyrazol-3-yl)pyridine) for the oxidation of benzyl alcohol was examined by $\mathrm{Hu}$ et al. [13]. The oxidation reactions were performed with $\mathrm{H}_{2} \mathrm{O}_{2}$ (30\% aq. solution) in acetonitrile, at $70{ }^{\circ} \mathrm{C}$. Interestingly, and in contrast with the majority of copper catalysts that afford mainly benzaldehyde under mild oxidation conditions, in the presence of 4 , after $1 \mathrm{~h}$ under the above mild peroxidative conditions, $98 \%$ of benzyl alcohol was converted to benzoic acid ( $96 \%$ yield, TON = 341, Scheme 2).

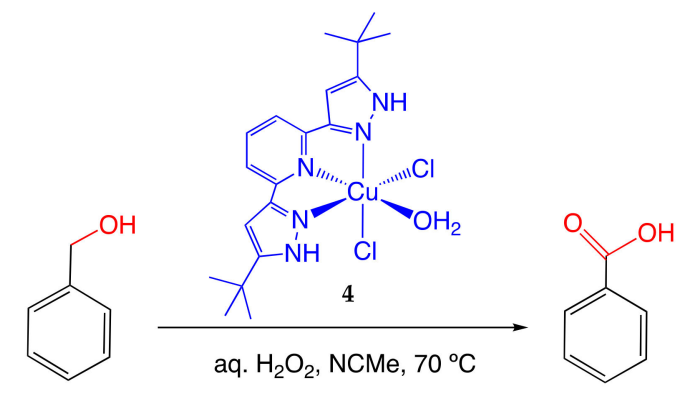

Scheme 2. Direct oxidation of benzyl alcohol to benzoic acid catalyzed by the mononuclear $\mathrm{Cu}(\mathrm{II})$ complex $\left[\mathrm{CuCl}_{2}\left(\mathrm{H}_{2} \mathrm{O}\right) \mathrm{L}\right](4)$.

\subsection{Oxidation with Tert-Butyl Hydroperoxide, Using Conventional Heating}

Despite $\mathrm{H}_{2} \mathrm{O}_{2}$ being the peroxide of election in terms of green chemical practices, its decomposition often hampers its use at moderate/high temperatures. Thus, tert-butyl hydroperoxide (TBHP), commercially available in a 70\% aqueous solution, appears usually as a suitable (although producing butanol) and economic alternative.

In 2017, Shul' pin and coworkers [14] applied the hexanuclear $\mathrm{Cu}(\mathrm{II})$-based phenylsilsesquioxane complex $\left[\left(\mathrm{PhSiO}_{1.5}\right)_{10}(\mathrm{CuO})_{6}\left(\mathrm{HO}_{0.5}\right)_{2}\left(\mathrm{C}_{12} \mathrm{H}_{8} \mathrm{~N}_{2}\right)_{2}\right](5)$ as catalyst for the oxidation of 1-phenylethanol with tert-butyl hydroperoxide (TBHP, $70 \%$ aq. solution) in acetonitrile, at $50{ }^{\circ} \mathrm{C}$ and in presence of $\mathrm{HNO}_{3}$, leading to $94 \%$ yield of acetophenone (TON $\left.=600\right)$ after $14 \mathrm{~h}$. Moreover, the cage-like compound $\left[\left(\mathrm{PhSiO}_{1,5}\right)_{6}\right]_{2}[\mathrm{CuO}]_{4}\left[\mathrm{NaO}_{0.5}\right]_{4}\left(\mathrm{dppmO}_{2}\right)_{2}(6)$, obtained very recently [15] by self-assembly synthesis, has also shown to be a very good catalyst for the oxidation of alcohols in acetonitrile solution: 1-phenylethanol was oxidized by TBHP to acetophenone in an almost quantitative yield. In addition, complexes bearing cyclic germsesquioxanes $\left[\mathrm{PhGeO}_{1,5}\right]_{5}$ and phenanthrolines, namely $\left[\left(\mathrm{PhGeO}_{1.5}\right)_{10}(\mathrm{CuO})_{6}\left(\mathrm{HO}_{0.5}\right)_{2}\left(\mathrm{C}_{12} \mathrm{H}_{8} \mathrm{~N}_{2}\right)_{2}\right]\left(\mathrm{H}_{2} \mathrm{O}\right)_{2}(7)$, exhibited high activity as pre-catalysts in homogeneous oxidations of cyclohexanol, 2-heptanol or 1-phenylethanol to the corresponding ketones, leading to yields up to $94 \%$ [16].

The mononuclear copper(II) complexes $\left[\mathrm{Cu}\left(\kappa O N N^{\prime}-\mathrm{HL}\right)\left(\mathrm{NO}_{3}\right)(\mathrm{DMF})\right]\left[\mathrm{NO}_{3}\right] \cdot \mathrm{H}_{2} \mathrm{O}(\mathbf{8}, \mathrm{DMF}=$ dimethylformamide) and $\left[\mathrm{Cu}\left(\kappa \mathrm{ONN}^{\prime}-\mathrm{HL}\right) \mathrm{Cl}_{2}\right] \cdot \frac{1}{2} \mathrm{DMSO}(9)$ (Figure 2) obtained from the Schiff base aminoalcohol HL (product of condensation of salicylic aldehyde and aminoethylpiperazine), were reported by Nesterov et al. [17] and tested as potential catalysts $(0.05-0.1 \mathrm{~mol} \%$ vs. substrate) for the 
oxidation of 1-phenylethanol to acetophenone with TBHP (2 eq. vs. substrate, $70 \%$ aq. solution). The reaction performed under additive-free conditions led to rather low ( $12 \%$ or $23 \%$ for 8 or $\mathbf{9}$, respectively) yields of acetophenone and TON values (246-468). The addition of either TEMPO free radical or $N$-hydroxyphthalimide (NHPI, precursor of phthalimido- $N$-oxyl radical) increased the yield and TON values for $\mathbf{8}$, whereas no significant influence of these additives was detected for 9. Whereas the presence of $\mathrm{HNO}_{3}$ hampered the oxidation reaction, the addition of $\mathrm{K}_{2} \mathrm{CO}_{3}$ significantly increased its rate. Moreover, the reaction strongly depended on the temperature: The activity of both 8 and 9 increased with the temperature, being the highest yield (62\% of acetophenone, for 8) and TON $(620$, for 8$)$ values reached at $100{ }^{\circ} \mathrm{C}$. Thus, in spite of the efforts of the authors, 8 and 9 remained as moderately active catalysts for the oxidation of 1-phenyl ethanol.

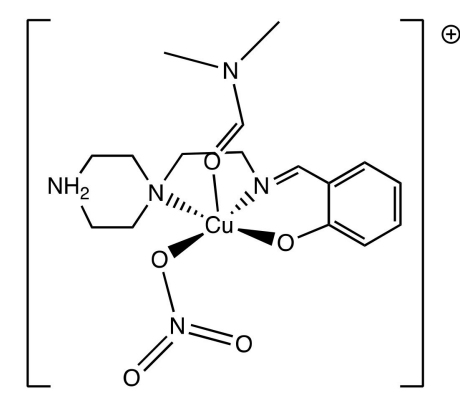

8

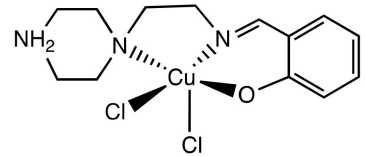

9

Figure 2. Mononuclear $\mathrm{Cu}(\mathrm{II})$ complexes $\left[\mathrm{Cu}\left(\kappa O N N^{\prime}-\mathrm{HL}\right)\left(\mathrm{NO}_{3}\right)(\mathrm{DMF})\right]\left(\mathrm{NO}_{3}\right) \cdot \mathrm{H}_{2} \mathrm{O}$ (8) and $\left[\mathrm{Cu}\left(\kappa \mathrm{ONN}^{\prime}-\mathrm{HL}\right) \mathrm{Cl}_{2}\right] \cdot \frac{1}{2} \mathrm{DMSO}(\mathbf{9})$.

\subsection{Microwave Assisted Oxidation with Tert-Butyl Hydroperoxide}

Another strategy followed by the researchers toward the improvement of the sustainability of the catalytic processes is the use of alternative energy sources where heating is required. Microwave (MW) irradiation turns out to be one of the most chosen alternative heating modes. In fact, MW irradiation promotes faster and more efficient internal heating through direct interaction between microwave energy and the reaction mixture components (solvents, reagents or catalysts). Therefore, while traditional conduction heating causes the mixture in contact with the reaction vessel wall to be heated first, microwave-radiation heating raises the temperature of the entire reaction system simultaneously. Compared to conventional heating, the use of microwave radiation has been shown to lead to a drastic reduction in reaction times, an increase in yield and selectivity observed in a number of chemical reactions, while also allowing a reduction or even elimination, in some cases, of the use of hazardous solvents.

In 2015, Martins et al. reported [18] the use of the mononuclear complexes [CuL( $\left.\left.\mathrm{H}_{2} \mathrm{O}\right)_{2}\right]\left(\mathbf{1 0}, \mathrm{H}_{2} \mathrm{~L}=\right.$ 2-[(2-hydroxy-3-methoxyphenyl)methylideneamino]benzenesulfonic acid) and [CuL(bipy)] DMF $\cdot \mathrm{H}_{2} \mathrm{O}$ (11), as well as of the diphenoxo-bridged dicopper compounds $[\mathrm{CuL}(\mathrm{py})]_{2}(\mathbf{1 2}, \mathrm{py}=$ pyridine $)$ and $[\mathrm{CuL}(\mathrm{EtOH})]_{2} \cdot 2 \mathrm{H}_{2} \mathrm{O}(\mathbf{1 3})$ (Figure 3), as selective catalysts for the neat-microwave-assisted oxidation of primary and secondary alcohols, under additive-free conditions. Moreover, 1-Phenylethanol was quantitatively converted into acetophenone (entry 5, Table 2), in the presence of 12 with turnover frequency (TOF) values up to $126.7 \mathrm{~min}^{-1}$, after $20 \mathrm{~min}$ of $\mathrm{MW}$ irradiation. Moreover, the almost quantitative conversion of benzyl alcohol to benzaldehyde (99\% yield, TOF $16.5 \mathrm{~min}^{-1}$, entry 6, Table 2) was also considered noticeable by the authors, since previous methods employing $\mathrm{Cu}(\mathrm{II})$ catalysts and TBHP under MW irradiation led to lower benzaldehyde yields (up to 75\%) and also needed higher reaction temperatures (up to $150{ }^{\circ} \mathrm{C}$ ) [16]. The selectivity of $\mathbf{1 3}$ to oxidize the alcohol relative to the ene function was evaluated by using cinnamyl alcohol as substrate and water as solvent, under the optimized conditions. Remarkably, cinnamaldehyde ( $85 \%$ yield, TOF $14.2 \mathrm{~min}^{-1}$ ) was the only product detected, clearly revealing the preference of $\mathbf{1 3}$ to oxidize the alcohol function. 
Table 2. Catalytic performances for copper complexes 10-26 in the neat MW-assisted oxidation of primary and secondary alcohols, using TBHP as the oxidant.

\begin{tabular}{|c|c|c|c|c|c|c|c|}
\hline Entry & Catalyst & Time (min.) & Substrate & Product & $\mathrm{T}\left({ }^{\circ} \mathrm{C}\right)$ & Yield (\%) & Ref. \\
\hline 1 & & 20 & 1-phenylethanol & acetophenone & \multirow{8}{*}{100} & 64 & \multirow{8}{*}{ [18] } \\
\hline 2 & $10^{a}$ & 150 & benzyl alcohol & benzaldehyde & & 58 & \\
\hline 3 & $11^{a}$ & 20 & 1-phenylethanol & acetophenone & & 52 & \\
\hline 4 & & 150 & benzyl alcohol & benzaldehyde & & 79 & \\
\hline 5 & \multirow{2}{*}{$12^{a}$} & 20 & 1-phenylethanol & acetophenone & & 100 & \\
\hline 6 & & 150 & benzyl alcohol & benzaldehyde & & 99 & \\
\hline 7 & \multirow{2}{*}{$13^{a}$} & 20 & 1-phenylethanol & acetophenone & & 94 & \\
\hline 8 & & 150 & benzyl alcohol & benzaldehyde & & 92 & \\
\hline 9 & & \multirow{6}{*}{30} & cyclohexanol & cyclohexanone & \multirow{6}{*}{60} & 85 & \multirow{6}{*}{ [19] } \\
\hline 10 & $14^{b}$ & & 1-phenylethanol & acetophenone & & 55 & \\
\hline 11 & & & benzyl alcohol & benzaldehyde & & 41 & \\
\hline 12 & \multirow{3}{*}{$15^{b}$} & & cyclohexanol & cyclohexanone & & 90 & \\
\hline 13 & & & 1-phenylethanol & acetophenone & & 58 & \\
\hline 14 & & & benzyl alcohol & benzaldehyde & & 49 & \\
\hline 15 & \multirow{4}{*}{$16^{c}$} & 5 & \multirow{7}{*}{ 1-phenylethanol } & \multirow{7}{*}{ acetophenone } & 120 & 100 & \\
\hline 16 & & 6 & & & 130 & 95 & 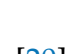 \\
\hline 17 & & 2 & & & 130 & 72 & [20] \\
\hline 18 & & 10 & & & 120 & 60 & \\
\hline 19 & $17^{d}$ & 30 & & & 120 & 99 & [21] \\
\hline 20 & $18^{e}$ & 60 & & & \multirow{2}{*}{120} & 81 & \multirow{2}{*}{ [22] } \\
\hline 21 & $19^{e}$ & & & & & 92 & \\
\hline $22^{f}$ & \multirow{3}{*}{20} & \multirow{3}{*}{60} & \multirow{3}{*}{$\begin{array}{c}\text { 1-phenylethanol } \\
\text { benzyl alcohol } \\
\text { cyclohexanol }\end{array}$} & acetophenone & \multirow{3}{*}{120} & 91 & \multirow{3}{*}{ [23] } \\
\hline $23^{g}$ & & & & benzaldehyde & & 41 & \\
\hline $24^{f}$ & & & & cyclohexanone & & 68 & \\
\hline 25 & $21^{h}$ & \multirow{7}{*}{30} & \multirow{7}{*}{ 1-phenylethanol } & \multirow{7}{*}{ acetophenone } & \multirow{7}{*}{120} & 79 & \multirow{7}{*}{ [24] } \\
\hline 26 & \multirow{2}{*}{$22^{h}$} & & & & & 66 & \\
\hline 27 & & & & & & 99 & \\
\hline 28 & $23^{h}$ & & & & & 81 & \\
\hline 29 & $24^{h}$ & & & & & 64 & \\
\hline 30 & $25^{h}$ & & & & & 68 & \\
\hline 31 & $26^{h}$ & & & & & 99 & \\
\hline $\begin{array}{l}{ }^{a} \mathrm{Al} \\
(2.5 \\
\text { cata } \\
(0.4 \\
(2.5 \\
\text { cata } \\
(5 \mathrm{~m} \\
{ }^{h} \mathrm{Al}\end{array}$ & $\begin{array}{l}\text { ohol }(2.5 \mathrm{mn} \\
\text { nmol), cataly } \\
\text { yst }(0.2 \mathrm{~mol} \% \\
\text { nol } \% \text { vs. al } \\
\text { nmol), cataly } \\
\text { yst }(0.2 \mathrm{~mol} \% \\
\text { nol), catalyst } \\
\text { ohol ( } 5 \mathrm{mmc}\end{array}$ & $\begin{array}{l}\text { 1), catalyst (0.04 } \\
(0.2 \mathrm{~mol} \% \text { vs. } \\
\text { vs. alcohol), TBl } \\
\text { hol), TBHP ( } 2 \\
\text { (0.4 mol } \% \text { vs. } \\
\text { s. alcohol), TBH } \\
.2 \text { mol } \% \text { vs. alc } \\
\text { catalyst ( } 0.2 \mathrm{~m}\end{array}$ & $\begin{array}{l}\text { ol\% vs. alcohol), TBH } \\
\text { ohol), TBHP ( } 2 \text { eq., } 70 \\
\left(2 \text { eq., } 70 \% \text { in } \mathrm{H}_{2} \mathrm{O}\right), \\
\left.., 70 \% \text { in } \mathrm{H}_{2} \mathrm{O}\right), 20 \\
\text { ohol), TBHP }(2 \text { eq., } 70 \\
\left(2 \text { eq., } 70 \% \text { in } \mathrm{H}_{2} \mathrm{O}\right), 5 \\
\text { ol), TBHP ( } 2 \text { eq., } 70 \% \\
\% \text { vs. alcohol), TBHP }\end{array}$ & $\begin{array}{l}\left(2 \text { eq., } 70 \% \text { in } \mathrm{H}_{2} \mathrm{O}\right. \\
\left.\text { in } \mathrm{H}_{2} \mathrm{O}\right), 10 \mathrm{~W} \text { MV } \\
-50 \mathrm{~W} \text { MW irradia } \\
\mathrm{MW} \text { irradiation, } \mathrm{n} \\
\left.6 \text { in } \mathrm{H}_{2} \mathrm{O}\right), 5-15 \mathrm{~W} \\
\text { MW irradiation, } \mathrm{n}( \\
\left.\mathrm{H}_{2} \mathrm{O}\right), 5 \mathrm{~W} \text { MW irre } \\
\left.\text { eq., } 70 \% \text { in } \mathrm{H}_{2} \mathrm{O}\right) \text {, }\end{array}$ & $\begin{array}{l}10 \mathrm{~W} \text { MV } \\
\text { rradiation } \\
\text { n. }{ }^{d} \text { Alco } \\
\text { EMPO)/n } \\
\text { V irradiat } \\
\text { MPO)/n( } \\
\text { ation, } \mathrm{n}(\mathrm{I}\end{array}$ & $\begin{array}{l}\text { adiation. }{ }^{b} \mathrm{~A} \\
\text { Alcohol }(2.5 \mathrm{r} \\
2.5 \mathrm{mmol}), \mathrm{c} \\
\text { alyst })=3 .{ }^{e} \mathrm{~A} \\
f \text { Alcohol }(5 \mathrm{r} \\
\mathrm{yst})=25 .{ }^{g} \mathrm{~A} \\
\mathrm{JH}) / \mathrm{n} \text { (catalys }\end{array}$ & $\begin{array}{l}\text { hol } \\
\text { ol), } \\
\text { lyst } \\
\text { hol } \\
\text { ol), } \\
\text { hol } \\
25 .\end{array}$ \\
\hline
\end{tabular}




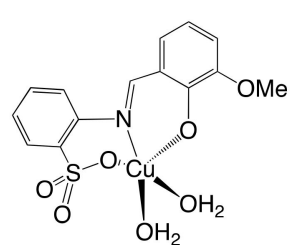

10

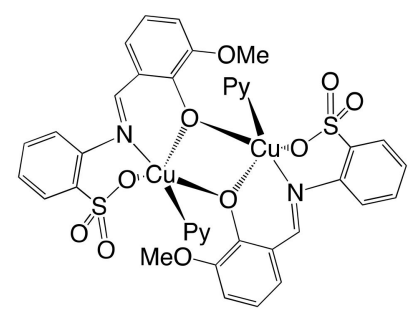

12

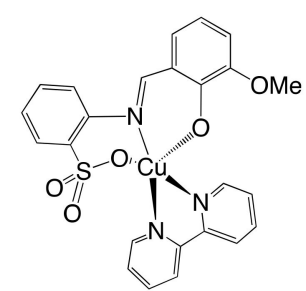

11

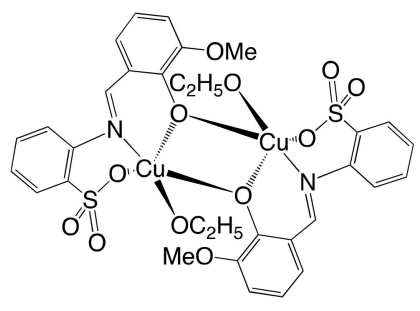

13

Figure 3. Mononuclear $\mathrm{Cu}(\mathrm{II})$ complexes $\left[\mathrm{CuL}\left(\mathrm{H}_{2} \mathrm{O}\right)_{2}\right](\mathbf{1 0})$ and $\left[\mathrm{CuL}(\right.$ bipy)$] \cdot \mathrm{DMF} \cdot \mathrm{H}_{2} \mathrm{O}(\mathbf{1 1})$, and the diphenoxo-bridged dicopper compounds $[\mathrm{CuL}(\mathrm{py})]_{2}(\mathbf{1 2})$ and $[\mathrm{CuL}(\mathrm{EtOH})]_{2} \cdot 2 \mathrm{H}_{2} \mathrm{O}(\mathbf{1 3})$.

An extension of this study to the preparation of further copper complexes with the above types of ligands was reported by the same authors in 2017 [19] (Figure 4). The dicopper(II) complex $\left[\mathrm{Cu}^{2}(\mathrm{~L}-\mathrm{kONO})_{2}\left(\mu-4,4^{\prime}\right.\right.$-bipy $\left.)(\mathrm{DMF})_{2}\right]\left(\mathbf{1 4}, \mathrm{H}_{2} \mathrm{~L}=2\right.$-[(2-hydroxy-3-methoxyphenyl)methylideneamino] benzenesulfonic acid) and the coordination polymer $\left[\mathrm{Cu}_{2}\left(\mu-\mathrm{L}-1 \kappa O N O^{\prime}: 2 \mathrm{\kappa O}\right)_{2}\left(\mu-4,4^{\prime}-\text { bipy }\right)\right]_{n} \cdot \mathrm{nH}_{2} \mathrm{O} \cdot \mathrm{nDMF}$ (15) were tested as catalysts for the oxidation of primary and secondary alcohols. A good catalytic activity for the neat and additive-free MW-assisted oxidation of the aliphatic cyclohexanol (up to $90 \%$ yield of cyclohexanone) after $30 \mathrm{~min}$ of low power MW irradiation (entries 9 and 12, Table 2) was achieved by these dinuclear $\mathrm{Cu}$ (II) compounds. Under the same reaction conditions, the conversion of the aryl 1-phenylethanol or benzyl alcohol occurred in to a much less extent (up to $58 \%$ and $49 \%$ for acetophenone and benzaldehyde, respectively, for 15, entries 13 and 14, Table 2).

Frija et al. developed [20] a new catalytic system for the MW-assisted neat oxidation of alcohols into the corresponding carbonyl derivatives. Thus, a mononuclear $\mathrm{Cu}(\mathrm{II})$ complex comprising the 2-methyltetrazole-saccharinate bidentate $N, N$-chelating ligand (16, Figure 5) was synthesized and found to exhibit a broad functional group compatibility, allowing efficient and selective conversion of a variety of secondary benzylic, allylic and aliphatic alcohols, including those with the functional groups susceptible to oxidation, such as internal alkenes or primary/secondary amines. Generally, the reactions were complete after 10-15 min of MW irradiation, at $80-130{ }^{\circ} \mathrm{C}$, with high TON and TOF values (up to 91.7 and $183.3 \mathrm{~min}^{-1}$, respectively) in additive-free and co-oxidant-free conditions. No significant conversion differences were observed for benzylic, allylic or aliphatic substrates. Moreover, the authors also found TEMPO acting as an inhibitor for $\mathbf{1 6}$ under the above peroxidative conditions.

In 2016, a different type of alcohol oxidation catalyst was reported by Galli and coworkers [21]: the thermal stable copper azolate/carboxylate compound $\left[\mathrm{Cu}(\mathrm{Hdmpzc})_{2}\right]\left(\mathbf{1 7}, \mathrm{H}_{2} \mathrm{dmpzc}=\right.$ 3,5-dimethyl-1H-pyrazol-4-carboxylic acid, Figure 5). Complex $\mathbf{1 7}$ was found to act as a remarkably active catalyst for the microwave-assisted oxidation of neat 1-phenylethanol to acetophenone as the only product. In fact, yields up to $99 \%$ at $120^{\circ} \mathrm{C}$ were achieved in only $0.5 \mathrm{~h}$ of MW irradiation (entry 19, Table 2). The hypothesis of recovering this homogeneous catalyst at the end of the first reaction run was hampered by its decomposition under the oxidation conditions.

$\mathrm{Cu}$ (II) complexes in two different tautomeric forms (keto and enol) derived from the aroylhydrazone Schiff base 2-hydroxy(2-hydroxybenzylidene)benzohydrazide $\left(\mathrm{H}_{2} \mathrm{~L}\right)$ were reported by Sutradhar et al. [22] (Figure 6). While the compound with the enol form of the ligand exists as the $1 \mathrm{D}$ polymer $\left[\mathrm{Cu}\left(1 \kappa N O O^{\prime}, 2 \kappa O^{\prime}, 3 \kappa O^{\prime \prime}-\mathrm{L}\right)\right]_{\mathrm{n}}(\mathbf{1 8})$, the one bearing the keto tautomer ligand occurs as the monomer $\left[\mathrm{Cu}(\mathrm{KNOO}-\mathrm{HL}) \mathrm{Cl}\left(\mathrm{CH}_{3} \mathrm{OH}\right)\right](19)$. Both complexes act as selective catalysts for the 
microwave-assisted oxidation of 1-phenylethanol with TBHP. Moreover, 19 exhibits the highest activity leading selectively to a maximum acetophenone yield of $92 \%$ (entry 22, Table 2).

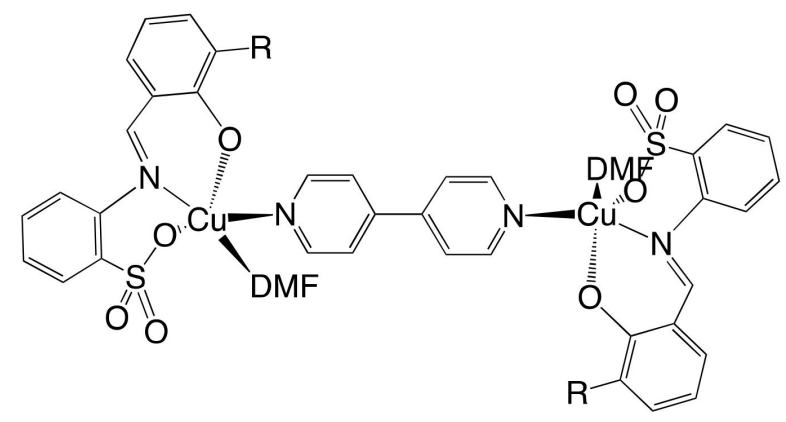

14

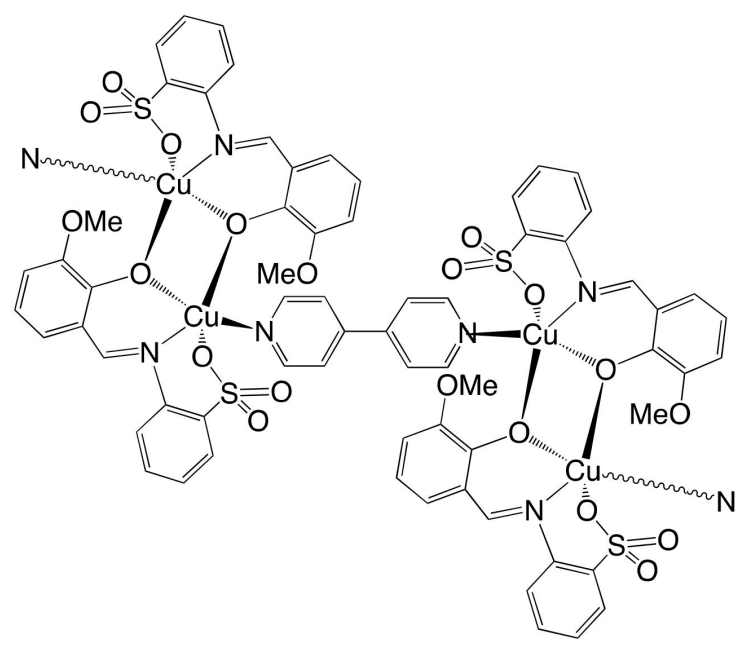

15

Figure 4. Dicopper(II) complex $\left[\mathrm{Cu}_{2}(\mathrm{~L}-\mathrm{kONO})_{2}\left(\mu-4,4^{\prime}\right.\right.$-bipy $\left.)(\mathrm{DMF})_{2}\right](\mathbf{1 4})$ and the dicopper(II)-based coordination polymer $\left[\mathrm{Cu}_{2}\left(\mu-\mathrm{L}-1 \kappa O N O^{\prime}: 2 \kappa \mathrm{O}\right)_{2}\left(\mu-4,4^{\prime}-\text { bipy }\right)\right]_{n} \cdot \mathrm{nH}_{2} \mathrm{O} \cdot \mathrm{nDMF}(15)$.

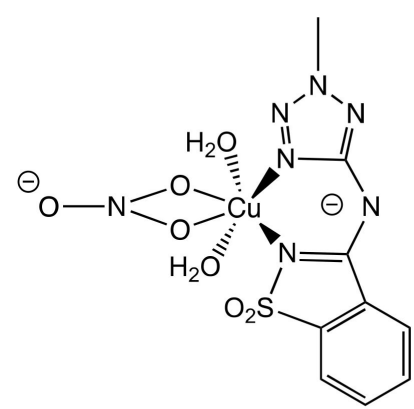

16<smiles>Cc1nonc1C</smiles>

17

Figure 5. Mononuclear $\mathrm{Cu}(\mathrm{II})$ complexes (16) and [Cu(Hdmpzc $\left.)_{2}\right]$ (17).

Very recently, the same authors reported [22] the catalytic activity of the related new mononuclear $\mathrm{Cu}$ (II) complex $\left[\mathrm{Cu}\left(\left(\mathrm{kNN}^{\prime} \mathrm{O}-\mathrm{HL}\right)\left(\mathrm{H}_{2} \mathrm{O}\right)_{2}\right]\left(\mathrm{NO}_{3}\right)\left(\mathbf{2 0}, \mathrm{H}_{2} \mathrm{~L}=N\right.\right.$-acetylpyrazine-2-carbohydrazide, Figure 6) for the oxidation of primary and secondary aryl alcohols (benzyl alcohol and 1-phenylethanol), and the secondary aliphatic cyclohexanol, using TBHP under added solvent-free microwave irradiation conditions. Compound 20 led to a maximum acetophenone yield of 91\% (entry 22, Table 2) in the presence of TEMPO as promoter for the oxidation of 1-phenylethanol, whereas $68 \%$ of cyclohexanone 
was attained in the same conditions. This behavior favoring the oxidation of aryl alcohols relative to the aliphatic ones, contrasts with that of the previously disclosed for complexes 14 and 15 (see above).

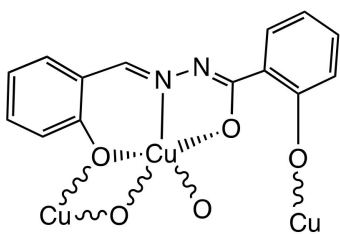

18<smiles>CO[C@]1(Cl)Oc2ccccc2CN1NNC(=O)c1ccccc1O</smiles>

19

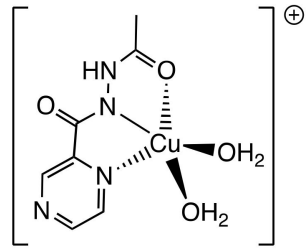

20

Figure 6. $\mathrm{Cu}(\mathrm{II})$ complexes $\left[\mathrm{Cu}\left(1 \kappa N O O^{\prime}, 2 \mathrm{kO}^{\prime}, 3 \kappa \mathrm{O}^{\prime \prime}-\mathrm{L}\right)\right]_{\mathrm{n}}(\mathbf{1 8}),\left[\mathrm{Cu}\left(\kappa N O O^{\prime}-\mathrm{HL}\right) \mathrm{Cl}\left(\mathrm{CH}_{3} \mathrm{OH}\right)\right](\mathbf{1 9})$ and $\left[\mathrm{Cu}\left(\left(\mathrm{kNN} N^{\prime} \mathrm{O}-\mathrm{HL}\right)\left(\mathrm{H}_{2} \mathrm{O}\right)_{2}\right]\left(\mathrm{NO}_{3}\right)(\mathbf{2 0})\right.$.

Recently, Ma et al. reported [24] new dinuclear compounds $\left[\mathrm{Cu}_{2}\left(\mathrm{OSO}_{2} \mathrm{CF}_{3}\right)_{2}(\mathrm{DMF})_{2} \mathrm{~L}\right]\left[\mathrm{SO}_{3} \mathrm{CF}_{3}\right]_{2}$ (21, L = 1,4,19,22,25,40-hexaaza-10,13,31,34-tetraoxa6,14,27,35(1,4)-tetrabenzenacyclopentacontane), $\left[\mathrm{Cu}_{2}\left(p-\mathrm{OSO}_{2} \mathrm{C}_{6} \mathrm{H}_{4} \mathrm{Me}\right)_{2} \mathrm{~L}(\mathrm{DMF})_{2}\right]\left(\mathrm{SO}_{3} \mathrm{C}_{6} \mathrm{H}_{4} \mathrm{Me}\right)_{2} \quad(\mathbf{2 2}), \quad\left[\mathrm{Cu}_{2}\left(\mathrm{ONO}_{2}\right)_{2} \mathrm{~L}(\mathrm{DMF})_{2}\right]\left(\mathrm{NO}_{3}\right)_{2} \quad(23)$, $\left[\mathrm{Cu}_{2}\left(\mathrm{OClO}_{3}\right)_{2}(\mathrm{DMF})_{2} \mathrm{~L}\right]\left(\mathrm{ClO}_{4}\right)_{2}(24),\left[\mathrm{Cu}_{2}(\mathrm{OOCPh})_{2} \mathrm{~L}\left(\mathrm{H}_{2} \mathrm{O}\right)_{2}\right]\left(\mathrm{O}_{2} \mathrm{CPh}\right)_{2}(25)$ and $\left[\mathrm{Cu}_{2}(\mathrm{OOCMe})_{4} \mathrm{~L}\right](26)$ (Figure 7), able to catalyze the microwave-assisted oxidation of neat 1-phenylethanol by TBHP, leading to acetophenone yields up to $99 \%$ and TOF values of $18.3 \mathrm{~min}^{-1}$, after $0.5 \mathrm{~h}$, without any additive. Complexes 22 and 26 present the highest catalytic activity (entries 27 and 31, Table 2) among these with the polyaza $\mathrm{N}_{6} \mathrm{O}_{4}$ macrocyclic ligand.

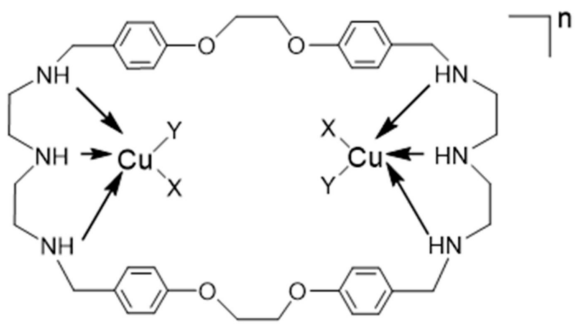

Figure 7. Dicopper(II) macrocyclic compounds $\left[\mathrm{n}=2+, \mathrm{X}=\mathrm{DMF}, \mathrm{Y}=\mathrm{OSO}_{2} \mathrm{CF}_{3}(\mathbf{2 1}) ; \mathrm{X}=\mathrm{DMF}, \mathrm{Y}=\right.$ $\mathrm{OSO}_{2} \mathrm{C}_{6} \mathrm{H}_{4} \mathrm{Me}(22) ; \mathrm{X}=\mathrm{DMF}, \mathrm{Y}=\mathrm{ONO}_{2}$ (23); $\mathrm{X}=\mathrm{DMF}, \mathrm{Y}=\mathrm{OClO}_{3}$ (24); $\mathrm{X}=\mathrm{H}_{2} \mathrm{O}, \mathrm{Y}=\mathrm{OCOPh}$ (25); $\mathrm{n}$ $=0, X=Y=$ OCOMe (26)].

Interestingly, such complexes (21-26) also act as catalysts for the aerobic oxidation of primary alcohols in the presence of TEMPO in alkaline solution (see Section 3, below).

To the best of our knowledge, during the 2015-2020 period, no significant advances regarding the mechanism of $\mathrm{Cu}$-catalyzed oxidation of alcohols with peroxide reagents were reported. The current well-established radical mechanism (Scheme 3) proposes the generation of $\mathrm{ROO}^{\bullet}$ and $\mathrm{RO}^{\bullet}$ radicals upon $\mathrm{Cu}$-assisted oxidation and reduction of the peroxide $(\mathrm{ROOH})$, which will behave as hydrogen abstractors from the alcohol to proceed the oxidation reaction.

$$
\begin{gathered}
\mathrm{Cu}^{(\mathrm{n}+1)+}+\mathrm{ROOH} \rightarrow \mathrm{Cu}^{\mathrm{n}+}+\mathrm{ROO}^{\prime}+\mathrm{H}^{+} \\
\mathrm{Cu}^{\mathrm{n}+}+\mathrm{ROOH} \rightarrow \mathrm{Cu}^{(\mathrm{n}+1)+}-\left(\mathrm{OH}^{-}\right)+\mathrm{RO} \\
\mathrm{Cu}^{(\mathrm{n}+1)+}-\left(\mathrm{OH}^{-}\right)+\mathrm{ROOH} \rightarrow \mathrm{Cu}^{(\mathrm{n}+1)+}-\left(\mathrm{OO}-\mathrm{R}^{-}\right)+\mathrm{H}_{2} \mathrm{O} \\
\mathrm{RO}^{\prime}+\mathrm{R}^{\prime}-\mathrm{OH} \rightarrow \mathrm{ROH}+\mathrm{R}^{\prime}-\mathrm{OH} \\
\mathrm{ROO}^{\prime}+\mathrm{R}^{\prime} \mathrm{OH} \rightarrow \mathrm{ROOH}+\mathrm{R}^{\prime}-\mathrm{OH} \\
\mathrm{Cu}^{(\mathrm{n}+1)+}-\left(\mathrm{OO}-\mathrm{R}^{-}\right)+\mathrm{R}^{\prime}-\mathrm{OH} \rightarrow \mathrm{R}^{\prime}{ }_{\mathrm{H}}=\mathrm{O}+\mathrm{ROOH}+\mathrm{Cu}^{\mathrm{n}+}
\end{gathered}
$$

Scheme 3. Possible pathways for the $\mathrm{Cu}$-assisted catalytic peroxidative oxidation of an alcohol ( $\left.\mathrm{R}^{\prime}-\mathrm{OH}\right)$. 


\section{Aerobic Oxidation of Alcohols}

The use of molecular oxygen as oxidant, in combination with a metal catalyst, has practical advantages due to the favorable economics associated with $\mathrm{O}_{2}$ and the formation of environmentally benign by-products: water and hydrogen peroxide. Copper would seem to be an appropriate choice for the selective catalytic oxidation of alcohols with dioxygen since it comprises the catalytic center in a variety of enzymes, e.g., galactose oxidase (which catalyzes this conversion in vivo) [25]. Thus, a process that may address green chemistry matters (see Section 1 ) would be the implementation of a $\mathrm{Cu}$-catalyst in combination with molecular oxygen as the oxidant. The low costs, ready availability of copper and the interesting spectroscopic properties of its coordination compounds resulted in the development of numerous $\mathrm{Cu}$-based catalysts for the aerobic oxidation of alcohols.

All the recently reported aerobic $\mathrm{Cu}$-based catalytic systems for alcohols oxidation, manly primary alcohols, encompass the 2,6,6-tetramethylpiperidine-1-oxyl radical (TEMPO). The nitroxyl radical, by itself, cannot catalyze the oxidation of alcohols by dioxygen, relying on the assistance of a co-catalyst to activate the oxidant [5]. The most used ones are first-row transition-metal coordination compounds where copper complexes bearing different $\mathrm{N}$-donor ligands account for the prime ones. In fact, as follows, the combination of a Cu-complex with TEMPO and dioxygen leads to very active catalytic systems for the selective oxidation of primary alcohols, in particular of benzyl alcohol to benzaldehyde.

The di-nuclear $\mathrm{Cu}$-compounds 21-26, recently disclosed by Ma et al. [24], besides catalyzing the MW-assisted peroxidative oxidation of 1-phenylethanol (see Section 2.3), in combination with TEMPO and in alkaline aq. solution, exhibit efficient catalytic activity for the aerobic oxidation of different alcohols to the corresponding aldehydes (yields up to $99 \%$ and TON values up 232 for benzaldehyde, entries $1-6$, Table 3 ) after $20 \mathrm{~h}$ at $70^{\circ} \mathrm{C}$. The formation of the corresponding carboxylic acid was not observed conceivably on account of the propensity of TEMPO for scavenging free radicals, acting as an effective radical trap, avoiding the auto-oxidation of aldehydes. Moreover, the reaction strongly depended on the temperature and for temperatures higher than $70{ }^{\circ} \mathrm{C}$, aldehyde yield values decrease conceivably due to the lower solubility of dioxygen in the reaction solution.

The catalytic activity of $\mathrm{Cu}(\mathrm{II})$ complexes bearing 2,2:6,2-terpyridine derivatives [ $\left.\mathrm{Cu}\left(4^{\prime}-\mathrm{Xtpy}\right) \mathrm{Cl}_{2}\right]$ [tpy = terpyridine; $\mathrm{X}=\mathrm{H}$ (27), $\mathrm{Cl}$ (28) or $\mathrm{CN}$ (29), Figure 8] was evaluated by Zhang et al. [26] for the oxidation of benzylic alcohol to benzaldehyde by air, in water and in the presence of TEMPO and $\mathrm{K}_{2} \mathrm{CO}_{3}$. Moreover, 27 led to $53 \%$ yield of benzaldehyde after $20 \mathrm{~h}$ at $70{ }^{\circ} \mathrm{C}$. In contrast, 28 catalyzed the reaction under the same conditions with a higher yield (74\%), whereas the conversion achieved with $\mathbf{2 9}$ was much lower (37\%) than that for the related catalysts $\mathbf{2 7}$ and 28. Interestingly, 27-29 acted as efficient catalysts (benzaldehyde yields 90\%-99\%, entries 7-9, Table 3) when, to the above reactions, 4-dimethylaminopyridine (DMAP) was added as an extra base. Moreover, the authors assessed the influence of TEMPO radical on the formation of new reactive intermediates during the catalytic oxidation reactions by introducing it into the reaction medium of the complex's formation. These coordination reactions in the presence of TEMPO led to the new mixed-valence $\mathrm{Cu}^{\mathrm{I}} \mathrm{Cu}^{\mathrm{II}}$ supramolecular assembles $\left[\mathrm{Cu}^{\mathrm{I}} \mathrm{Cu}^{\mathrm{II}}(\mathrm{tpy}) \mathrm{Cl}_{3}\right]$ (30) and $\left[\mathrm{Cu}(4-\mathrm{Cltpy}) \mathrm{Cl}\left(\mathrm{CuCl}_{2}\right)\right]_{n}(\mathbf{3 1})$. Complexes 30 and 31 exhibited higher catalytic activity than those of the mononuclear complexes under milder conditions: Quantitative conversions (TOF ca. $0.3 \mathrm{~min}^{-1}$ ) were obtained within $5 \mathrm{~h}$ in both cases (entries 10 and 11, Table 3), even though the reactions were performed at room temperature.

Pombeiro and coworkers reported [27] the first example of a copper complex based on 3,7-diacetyl1,3,7-triaza-5-phosphabicyclo [3.3.1]nonane-5-oxide $(\mathrm{DAPTA}=\mathrm{O})$ ligand, $\left[\mathrm{Cu}\left(\mu-\mathrm{CH}_{3} \mathrm{COO}\right)_{2}(\mathrm{kO}-\mathrm{DAPTA}\right.$ $=\mathrm{O})]_{2}$ (32, Figure 8). The catalytic activity of 32 was evaluated for the aerobic TEMPO-mediated oxidation of benzyl alcohol (entries 12-14, Table 3), and of 3,5-di-tert-butylcatechol (model substrate for catechol oxidase) [28]. The kinetic data fit the Michaelis-Menten equation, and the rate constant obtained is among the highest obtained for 3,5-di-tert-butylcatechol (using di-nuclear copper(II) complexes). DFT calculations suggested a mixed valence $\mathrm{Cu}{ }^{\mathrm{II}} / \mathrm{Cu}^{\mathrm{I}}$ complex intermediate, (Figure 9 ) in which the spin electron density is mostly concentrated at one of the $\mathrm{Cu}$ atoms and at the DAPTA $=\mathrm{O}$ ligand. 


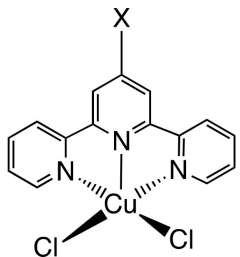

$27(X=H), 28(X=C l), 29(X=C N)$

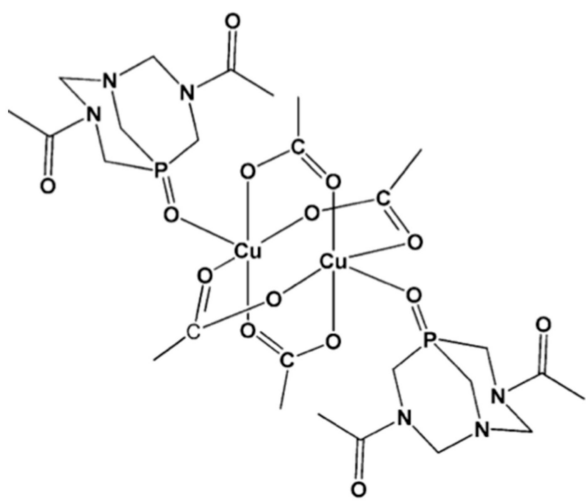

32

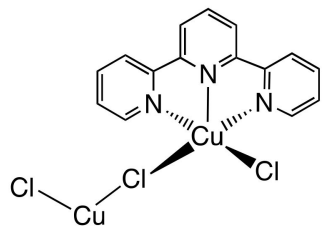

30<smiles></smiles>

31

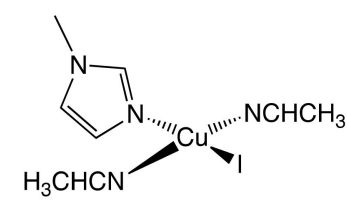

33

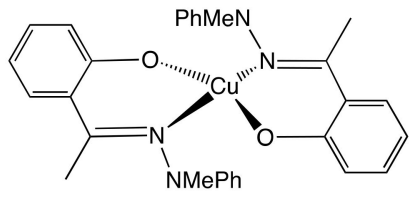

34

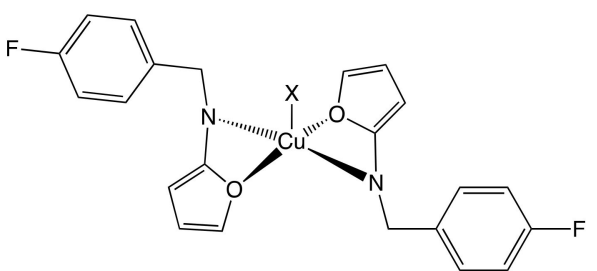

$35(X=\mathrm{Br}), 36(\mathrm{X}=\mathrm{OTf})$

Figure 8. Copper complexes $\left[\mathrm{CuCl}_{2}\left(4^{\prime}-\mathrm{Xtpy}\right)\right][\mathrm{X}=\mathrm{H}(\mathbf{2 7}), \mathrm{Cl}(\mathbf{2 8})$ or $\mathrm{CN}(29)],\left[\mathrm{Cu}^{\mathrm{I}} \mathrm{Cu}^{\mathrm{II}}(\mathrm{tpy}) \mathrm{Cl}_{3}\right](\mathbf{3 0})$, $\left[\mathrm{Cu}\left(4^{\prime}-\mathrm{Cltpy}\right) \mathrm{Cl}\left(\mathrm{CuCl}_{2}\right)\right]_{n}(31),\left[\mathrm{Cu}^{\mathrm{II}}\left(\mu-\mathrm{CH}_{3} \mathrm{COO}\right)_{2}(k \mathrm{O}-\mathrm{DAPTA}=\mathrm{O})\right]_{2}(32),\left[\mathrm{CuI}(\mathrm{NMI})(\mathrm{NCMe})_{2}\right](33)$, $\left[\mathrm{Cu}\left(\mathrm{L}^{\mathrm{NNMePh}}\right)_{2}\right](34)$ and $\left[\mathrm{CuX}\left(\mathrm{C}_{11} \mathrm{H}_{8} \mathrm{FNO}\right)_{2}\right][\mathrm{X}=\mathrm{Br}(\mathbf{3 5})$ or $\mathrm{X}=\mathrm{OTf}(\mathbf{3 6})]$.<smiles></smiles>

Figure 9. Proposed intermediate formed in the oxidation of 3,5-di-tert-butylcatechol catalyzed by complex 32 (the DAPTA = O ligands are omitted for clarity).

The knowledge that external bases have an effect on the catalytic activity, as well as on the selectivity and stability of the catalytic systems, has led to the development of new ones able to operate in the absence of an added base [29]. Theoretical and experimental studies revealed that appropriate ligands enhance the electron density of the $\mathrm{Cu}$ center (e.g., by ligand-to-metal charge transfer (LMCT)), leading to a complex with a suitable alkalinity and suggesting that a basic anion in the Cu-complex could be more efficient for promoting the oxidation reaction than an external base added.

Liu et al. reported [30] the homogeneous $\mathrm{Cu}(\mathrm{I}) / \mathrm{NMI} / \mathrm{TEMPO}$ catalytic system (NMI = methyl imidazole) for the aerobic oxidation of 1-octanol (99\% of octanal after $24 \mathrm{~h}$ ) and other alcohols (e.g., benzyl alcohol, entry 15, Table 3) into the corresponding aldehydes, at room temperature, in acetonitrile. The catalytic species was found to be the $\mathrm{Cu}(\mathrm{I})$ complex [CuI(NMI)(NCMe) $)_{2}$ (33, Figure 8), where the labile solvent binding to the copper center is crucial to ensure both oxygen and alcohol coordination. 
Moreover, NMI, as ligand, improved the $\mathrm{Cu}(\mathrm{I})$ center electron density and endorsed $\mathrm{O}_{2}$ coordination. In particular, the system exhibited strong oxidizing ability to quantitative conversion of benzylic alcohols (entry 15, Table 3), regardless of the substituents on the phenyl ring, and of allylic alcohols into aldehydes.

Table 3. Catalytic performances of copper complexes 21-35 for the selective aerobic oxidation of benzyl alcohol to benzaldehyde.

\begin{tabular}{|c|c|c|c|c|c|}
\hline Entry & Catalyst & Time (h) & $\mathrm{T}\left({ }^{\circ} \mathrm{C}\right)$ & Yield (\%) & Ref. \\
\hline 1 & 21 & \multirow{6}{*}{$20^{a}$} & \multirow{6}{*}{70} & 97 & \multirow{6}{*}{ [24] } \\
\hline 2 & 22 & & & 99 & \\
\hline 3 & 23 & & & 94 & \\
\hline 4 & 24 & & & 79 & \\
\hline 5 & 25 & & & 84 & \\
\hline 6 & 26 & & & 99 & \\
\hline 7 & 27 & \multirow{3}{*}{$20^{b}$} & \multirow{3}{*}{70} & 95 & \multirow{5}{*}{ [26] } \\
\hline 8 & 28 & & & $>99$ & \\
\hline 9 & 29 & & & 90 & \\
\hline 10 & 30 & \multirow{2}{*}{$5^{b}$} & \multirow{2}{*}{25} & $>99$ & \\
\hline 11 & 31 & & & $>99$ & \\
\hline 12 & \multirow{3}{*}{$32^{c}$} & 6 & \multirow{3}{*}{80} & 41 & \multirow{3}{*}{ [27] } \\
\hline 13 & & 21 & & 78 & \\
\hline 14 & & 48 & & 89 & \\
\hline 15 & $33^{d}$ & 24 & 25 & 99 & [29] \\
\hline 16 & \multirow{2}{*}{$34^{e}$} & 18 & 25 & 10 & \multirow[t]{2}{*}{ [31] } \\
\hline 17 & & 6 & 60 & 14 & \\
\hline 18 & $35^{f}$ & 1 & 25 & $>99$ & [32] \\
\hline
\end{tabular}

${ }^{a}$ Alcohol (1.5 mmol), catalyst $\left(0.5 \mathrm{~mol} \%\right.$ vs. alcohol), TEMPO (5 mol\% vs. alcohol), $\mathrm{K}_{2} \mathrm{CO}_{3}(0.1 \mathrm{M}) .{ }^{b}$ Alcohol $(1.0 \mathrm{mmol})$, catalyst $(0.01 \mathrm{mmol}), \mathrm{DMAP}(0.050 \mathrm{mmol}), \mathrm{TEMPO}(0.050 \mathrm{mmol}), \mathrm{K}_{2} \mathrm{CO}_{3}(0.2 \mathrm{M})$, water. ${ }^{c}$ Alcohol $(0.5 \mathrm{mmol})$, catalyst ( $5 \mathrm{~mol} \%$ vs. alcohol), TEMPO $(5 \mathrm{~mol} \%), \mathrm{K}_{2} \mathrm{CO}_{3}(0.1 \mathrm{M}) .{ }^{d}$ Alcohol $(5 \mathrm{mmol})$, catalyst $(0.25 \mathrm{mmol})$, TEMPO ( $5 \mathrm{~mol} \%)$, acetonitrile. ${ }^{e}$ Alcohol ( $1.0 \mathrm{mmol}$ ), catalyst ( $5 \mathrm{~mol} \% \mathrm{vs}$. alcohol), TEMPO (5 mol $\left.\%\right)$, NMI (10 mol\%), acetonitrile. ${ }^{f}$ Alcohol $(1.0 \mathrm{mmol})$, catalyst ( $5 \mathrm{~mol} \%$ vs. alcohol), TEMPO (5 mol\%), NMI (10 mol\%), acetonitrile, open air.

The catalytic activity of the copper(II) complex $\left[\mathrm{Cu}\left(\mathrm{L}^{\mathrm{NNMePh}}\right)_{2}\right](34)\left[\mathrm{L}^{\mathrm{NNMePh}}=\kappa^{2}-\mathrm{N}, \mathrm{O}-2-(1-(2-\right.$ methyl-2-phenylhydrazono)ethyl)phenolate, Figure 8] in combination with TEMPO was evaluated, by Conejo et al. [31], for the oxidation of benzyl alcohol by air, in toluene. Very low yields of benzaldehyde were attained (up to $14 \%$ after $6 \mathrm{~h}$ at $60^{\circ} \mathrm{C}$, or $10 \%$ after $18 \mathrm{~h}$ at r.t., entries 16 and 17 , respectively, Table 3).

Repo and coworkers disclosed [32] a new $\mathrm{Cu}(\mathrm{I})$ complex bearing $N$-(4-fluorophenyl)-1(furan-2-yl)methanimine $\left(\mathrm{C}_{11} \mathrm{H}_{8} \mathrm{FNO}\right)\left[\mathrm{CuBr}\left(\mathrm{C}_{11} \mathrm{H}_{8} \mathrm{FNO}\right)_{2}\right]$ (35, Figure 8) acting as catalyst for the selective oxidation of several primary alcohols to aldehydes under ambient (r.t.), conditions (with air, TEMPO and NMI in acetonitrile). 35 exhibited high activity, leading to, e.g., nearly quantitative yields of aldehydes (e.g., $1 \mathrm{~h}$ of oxidation of benzyl alcohol at r.t. yielded $99 \%$ of benzaldehyde, entry 18 , Table 3). Moreover, replacing the coordinated bromide by triflate, to generate $\left[\mathrm{Cu}(\mathrm{OTf})\left(\mathrm{C}_{11} \mathrm{H}_{8} \mathrm{FNO}\right)_{2}\right]$ (36) $\left(\mathrm{OTf}=\mathrm{CF}_{3} \mathrm{SO}_{3}\right.$, Figure 8), led to an increase in the product yields of the primary alcohols oxidation. This was considered by the authors to be a remarkable catalytic result, as the oxidation reactions occurred in open air (rather than under pure oxygen) and at room temperature. Secondary alcohols, such as 2-octanol, were hardly oxidized, due to the steric bulkiness of TEMPO. 
In situ formed $\mathrm{Cu}(\mathrm{I}) / \mathrm{TEMPO}-$ based catalytic systems have also been reported for the successful oxidation of several alcohol substrates, including those previously found as problematic.

Swarts et al. [33] reported a in situ $\mathrm{Cu}(\mathrm{I}) / \mathrm{TEMPO} / \mathrm{NMI}$ catalyst system formed with a bis(pyridyl)- $\mathrm{N}$ alkylamine. Quantitative conversion of 1-octanol was achieved, even though the reaction rate for this ligand was slightly slower than for the previously used bipy. A variety of primary aliphatic, allylic, benzylic and heterocyclic alcohols was also converted, with excellent yields of the corresponding aldehydes, whereas secondary alcohols could not be oxidized on account of the steric effect exerted during the (bulky) TEMPO-mediated hydrogen abstraction from the alcohol.

Recently, a highly efficient $\mathrm{Cu}(\mathrm{I}) / \mathrm{TEMPO}$ catalytic system for the (fast) aerobic oxidation of an aliphatic alcohol (intermediate in a pharmaceutical synthesis) to the corresponding aldehyde was developed by Roberts et al. [34], which appears suitable for safe large-scale application in a batch reactor. A number of key by-products (some not previously reported for $\mathrm{Cu}(\mathrm{I}) /$ nitroxyl-catalyzed aerobic alcohol oxidation) that affect catalyst performance and aldehyde yield were identified with the help of kinetic information and allowed the scale up of the oxidation reaction, with bubbling air, in a batch reactor.

The mechanistic pathway of aerobic oxidations of alcohols catalyzed by $\mathrm{Cu} / \mathrm{TEMPO}$ systems has been investigated by several research groups [35-40], and these investigations have led to partially contradicting mechanistic proposals involving either TEMPO+, TEMPO- or TEMPO-H as the reactive intermediate; moreover, this was recently thoroughly revised by Swarts et al. [28].

\section{Conclusions}

Important advances are being made in the design strategies for selective catalytic oxidations of primary and secondary alcohols. Clean oxidants, such as dioxygen or peroxides in aqueous, mono- or bi-phasic systems, as well as neat oxidations, are significantly increasing. In addition, taking advantage of non-conventional reaction conditions, such as microwave-assisted oxidations, or selecting catalysts of inexpensive and environmentally benign first-row-transition metals, with copper as one of the most preferred, are noticeable trends. Thus, $\mathrm{Cu}$ /peroxide- or $\mathrm{Cu} / \mathrm{O}_{2}$-based catalytic systems could constitute attractive alternatives to traditional oxidation methods, although challenges to find the optimal catalyst for oxidizing both primary and secondary alcohols remain. Nevertheless, considering the pace of advances in recent years, it is expectable that such issues will be soon addressed.

Funding: This work was supported by the Fundação para a Ciência e Tecnologia (FCT), project UIDB/00100/2020 of Centro de Química Estrutural and PTDC/QEQ-ERQ/1648/2014 project

Conflicts of Interest: The authors declare no conflicts of interest.

\section{References}

1. Jiao, N.; Stahl, S.S. (Eds.) Green Oxidation in Organic Synthesis; Wiley-VCH: Weinheim, Germany, 2019; ISBN 978-1-119-30404-3.

2. Cardona, F.; Parmeggiani, C. (Eds.) Transition Metal. Catalysis in Aerobic Alcohol Oxidation Synthesis; RSC Green Chemistry Series; RSC Publishers: Cambridge, UK, 2014; ISBN 9781849738231.

3. Tojo, G.; Fernandez, M.I. (Eds.) Oxidation of Alcohols to Aldehydes and Ketones: A Guide to Current Practice; Springer: Berlin, Germany, 2006; pp. 241-253.

4. Arends, I.W.C.E.; Sheldon, R.A. Modern Oxidation Methods, 2nd ed.; Backvall, J.-E., Ed.; Wiley VCH: Weinheim, Germany, 2010; pp. 147-185.

5. Kopylovich, M.N.; Ribeiro, A.P.C.; Alegria, E.C.B.A.; Martins, N.M.R.; Martins, L.M.D.R.S.; Pombeiro, A.J.L. Catalytic oxidation of alcohols: Recent advances. Adv. Organometal. Chem. 2015, 63, 91-174.

6. Gamez, P.; Aubel, P.G.; Driessen, W.L.; Reedijk, J. Homogeneous bio-inspired copper-catalyzed oxidation reactions. Chem. Soc. Rev. 2001, 30, 376-385. [CrossRef]

7. Lewis, E.A.; Tolman, W.B. Reactivity of Dioxygen-Copper Systems. Chem. Rev. 2004, 104, 1047-1076. [CrossRef] [PubMed] 
8. Sheldon, R.A. Recent advances in green catalytic oxidations of alcohols in aqueous media. Catal. Today 2015, 247, 4-13. [CrossRef]

9. Ma, Z.; Wei, L.; Alegria, E.C.B.A.; Martins, L.; Da Silva, M.F.C.G.; Pombeiro, A.J.L. Synthesis and characterization of copper(ii) 4 ' - phenyl-terpyridine compounds and catalytic application for aerobic oxidation of benzylic alcohols. Dalton Trans. 2014, 43, 4048. [CrossRef] [PubMed]

10. Ünver, H.; Kani, I. Homogeneous oxidation of alcohols in water catalyzed with $\mathrm{Cu}(\mathrm{II})$-triphenyl acetate/bipyridyl complex. Polyhedron 2017, 134, 257-262. [CrossRef]

11. Ünver, H.; Kani, I. Homogeneous oxidation of alcohol and alkene with copper (II) complex in water. J. Chem. Sci. 2018, 130, 33. [CrossRef]

12. Ünver, H. Crystal structure of an alkoxide bridged dinuclear copper(II) complex: Mild and selective oxidation of primary and secondary alcohols in water. Transit. Met. Chem. 2018, 43, 641-646. [CrossRef]

13. Wu, C.; Liu, B.; Geng, X.; Zhang, Z.; Liu, S.; Hu, Q. Selective Catalytic Oxidation of Aromatic Substrates Employing Mononuclear Copper(II) Catalyst with $\mathrm{H}_{2} \mathrm{O}_{2}$. Polyhedron 2018, 158, 334-341. [CrossRef]

14. Kulakova, A.N.; Bilyachenko, A.N.; Levitsky, M.M.; Khrustalev, V.N.; Korlyukov, A.A.; Zubavichus, Y.V.; Dorovatovskii, P.V.; Lamaty, F.; Bantreil, X.; Villemejeanne, B.; et al. Si10Cu6N4 Cage Hexacoppersilsesquioxanes Containing N Ligands: Synthesis, Structure, and High Catalytic Activity in Peroxide Oxidations. Inorg. Chem. 2017, 56, 15026-15040. [CrossRef]

15. Kulakova, A.N.; Khrustalev, V.N.; Zubavichus, Y.V.; Shul'Pina, L.S.; Shubina, E.S.; Levitsky, M.M.; Ikonnikov, N.S.; Bilyachenko, A.N.; Kozlov, Y.N.; Shul'Pin, G.B. Palanquin-Like $\mathrm{Cu}_{4} \mathrm{Na}_{4}$ Silsesquioxane Synthesis (via Oxidation of 1,1-bis(Diphenylphosphino)methane), Structure and Catalytic Activity in Alkane or Alcohol Oxidation with Peroxides. Catalysts 2019, 9, 154. [CrossRef]

16. Kulakova, A.N.; Korlyukov, A.A.; Zubavichus, Y.V.; Khrustalev, V.N.; Bantreil, X.; Shul'Pina, L.S.; Levitsky, M.M.; Ikonnikov, N.S.; Shubina, E.S.; Lamaty, F.; et al. Hexacoppergermsesquioxanes as complexes with N-ligands: Synthesis, structure and catalytic properties. J. Organomet. Chem. 2019, 884, 17-28. [CrossRef]

17. Nesterova, O.V.; Nesterov, D.S.; Krogul-Sobczak, A.; Da Silva, M.F.C.G.; Pombeiro, A.J. Synthesis, crystal structures and catalytic activity of $\mathrm{Cu}(\mathrm{II})$ and $\mathrm{Mn}$ (III) Schiff base complexes: Influence of additives on the oxidation catalysis of cyclohexane and 1-phenylehanol. J. Mol. Catal. A: Chem. 2017, 426, 506-515. [CrossRef]

18. Hazra, S.; Martins, L.M.D.R.S.; Guedes da Silva, M.F.C.; Pombeiro, A.J.L. Sulfonated Schiff base copper(II) complexes as efficient and selective catalysts in alcohol oxidation: Syntheses and crystal structures. RSC Adv. 2015, 5, 90079-90088. [CrossRef]

19. Hazra, S.; Martins, L.M.; Da Silva, M.F.C.G.; Pombeiro, A.J. Sulfonated Schiff base dimeric and polymeric copper(II) complexes: Temperature dependent synthesis, crystal structure and catalytic alcohol oxidation studies. Inorganica Chim. Acta 2017, 455, 549-556. [CrossRef]

20. Frija, L.M.; Alegria, E.C.; Sutradhar, M.; Cristiano, M.L.S.; Ismael, A.; Kopylovich, M.N.; Pombeiro, A.J. Copper(II) and cobalt(II) tetrazole-saccharinate complexes as effective catalysts for oxidation of secondary alcohols. J. Mol. Catal. A: Chem. 2016, 425, 283-290. [CrossRef]

21. Tăbăcaru, A.; Xhaferaj, N.; Martins, L.M.D.R.S.; Alegria, E.C.B.A.; Chay, R.S.; Giacobbe, C.; Domasevitch, K.V.; Pombeiro, A.J.L.; Galli, S.; Pettinari, C. Metal Azolate/Carboxylate Frameworks as Catalysts in Oxidative and C-C Coupling Reactions. Inorg. Chem. 2016, 55, 5804-5817. [CrossRef]

22. Sutradhar, M.; Alegria, E.C.; Barman, T.R.; Scorcelletti, F.; Da Silva, M.F.C.G.; Pombeiro, A.J. Microwave-assisted peroxidative oxidation of toluene and 1-phenylethanol with monomeric keto and polymeric enol aroylhydrazone Cu(II) complexes. Mol. Catal. 2017, 439, 224-232. [CrossRef]

23. Sutradhar, M.; Barman, T.R.; Pombeiro, A.J.L.; Martins, L.M.D.R.S. Cu(II) and Fe(III) Complexes Derived from N-Acetylpyrazine-2-Carbohydrazide as Efficient Catalysts Towards Neat Microwave Assisted Oxidation of Alcohols. Catalysts 2019, 9, 1053. [CrossRef]

24. Ma, Z.; Wang, Q.; Alegria, E.C.B.A.; Da Silva, M.F.C.G.; Martins, L.M.D.R.S.; Telo, J.P.; Correia, I.; Pombeiro, A.J.L. Synthesis and Structure of Copper Complexes of a N6O4 Macrocyclic Ligand and Catalytic Application in Alcohol Oxidation. Catalysts 2019, 9, 424. [CrossRef]

25. Ito, N.; Phillips, S.E.V.; Stevens, C.; Ogel, Z.B.; McPherson, M.J.; Keen, J.N.; Yadav, K.D.S.; Knowles, P.F. Novel thioether bond revealed by a $1.7 \AA$ A crystal structure of galactose oxidase. Nature 1991, 350, 87-90. [CrossRef] [PubMed] 
26. Zhang, G.; Liu, E.; Yang, C.; Li, L.; Golen, J.A.; Rheingold, A.L. Copper(II) Complexes of 2,2' :6' ,2"'-Terpyridine Derivatives for Catalytic Aerobic Alcohol Oxidations - Observation of Mixed-Valence $\mathrm{Cu}^{\mathrm{I}} \mathrm{Cu}^{\mathrm{II}}$ Assembles. Eur. J. Inorg. Chem. 2015, 2015, 939-947. [CrossRef]

27. Mahmoud, A.G.; Da Silva, M.F.C.G.; Sliwa, E.I.; Smolenski, P.; Kuznetsov, M.L.; Pombeiro, A.J.L. Copper(II) and Sodium(I) Complexes based on 3,7-Diacetyl-1,3,7-triaza-5-phosphabicyclo[3.3.1]nonane-5-oxide: Synthesis, Characterization, and Catalytic Activity. Chem. Asian J. 2018, 13, 2868-2880. [CrossRef] [PubMed]

28. Ribeiro, A.P.; Martins, L.M.; Hazra, S.; Pombeiro, A.J. Catalytic oxidation of cyclohexane with hydrogen peroxide and a tetracopper(II) complex in an ionic liquid. Comptes Rendus Chim. 2015, 18, 758-765. [CrossRef]

29. Marais, L.; Swarts, A.J. Biomimetic Cu/Nitroxyl Catalyst Systems for Selective Alcohol Oxidation. Catalysts 2019, 9, 395. [CrossRef]

30. Liu, Z.; Shen, Z.; Zhang, N.; Zhong, W.; Liu, X. Aerobic Oxidation of Alcohols Catalysed by Cu(I)/NMI/TEMPO System and Its Mechanistic Insights. Catal. Lett. 2018, 148, 2709-2718. [CrossRef]

31. Conejo, M.D.M.; Cantero, J.; Pastor, A.; Álvarez, E.; Galindo, A. Synthesis, structure and properties of nickel and copper complexes containing N,O -hydrazone Schiff base ligand. Inorganica Chim. Acta 2018, 470, 113-118. [CrossRef]

32. Lagerspets, E.; Lagerblom, K.; Heliövaara, E.; Hiltunen, O.-M.; Moslova, K.; Nieger, M.; Repo, T. Schiff base $\mathrm{Cu}(\mathrm{I})$ catalyst for aerobic oxidation of primary alcohols. Mol. Catal. 2019, 468, 75-79. [CrossRef]

33. Marais, L.; Burés, J.; Jordaan, J.H.L.; Mapolie, S.; Swarts, A.J. A bis(pyridyl)-N-alkylamine/Cu(i) catalyst system for aerobic alcohol oxidation. Org. Biomol. Chem. 2017, 15, 6926-6933. [CrossRef]

34. Ochen, A.; Whitten, R.; Aylott, H.E.; Ruffell, K.; Williams, G.D.; Slater, F.; Roberts, A.; Evans, P.; Steves, J.E.; Sanganee, M.J. Development of a Large-Scale Copper(I)/TEMPO-Catalyzed Aerobic Alcohol Oxidation for the Synthesis of LSD1 Inhibitor GSK2879552. Organometallics 2019, 38, 176-184. [CrossRef]

35. Duan, R.F.; Zhang, Q.C.; Ma, L.S.; Cheng, L.; Yang, J.C. Mechanistic insight into the aerobic oxidation of benzyl alcohol catalyzed by the Cu II -TEMPO catalyst in alkaline water solution. RSC Adv. 2015, 5, 83976-83984. [CrossRef]

36. Rabeah, J.; Bentrup, U.; Stößer, R.; Brückner, A. Selective Alcohol Oxidation by a Copper-TEMPO Catalyst: Mechanistic Insights by Simultaneously Coupled Operando EPR/UV-Vis/ATR-IR Spectroscopy. Angew. Chem. 2015, 127, 11957-11960. [CrossRef]

37. Wang, L.; Bie, Z.; Shang, S.; Lv, Y.; Li, G.; Niu, J.; Gao, S. Bioinspired aerobic oxidation of alcohols with a bifunctional ligand based on bipyridine and TEMPO. RSC Adv. 2016, 6, 35008-35013. [CrossRef]

38. Prathap, K.J.; Maayan, G. Metallopeptoids as efficient biomimetic catalysts. Chem. Commun. 2015, 51, 11096-11099. [CrossRef]

39. Walroth, R.C.; Miles, K.C.; Lukens, J.T.; Macmillan, S.N.; Stahl, S.S.; Lancaster, K.M. Electronic Structural Analysis of Copper(II)-TEMPO/ABNO Complexes Provides Evidence for Copper(I)-Oxoammonium Character. J. Am. Chem. Soc. 2017, 139, 13507-13517. [CrossRef]

40. McCann, S.D.; Lumb, J.-P.; Arndtsen, B.A.; Stahl, S.S. Second-Order Biomimicry: In Situ Oxidative Self-Processing Converts Copper(I)/Diamine Precursor into a Highly Active Aerobic Oxidation Catalyst. ACS Central Sci. 2017, 3, 314-321. [CrossRef]

Sample Availability: Samples of the compounds are not available from the authors.

(C) 2020 by the authors. Licensee MDPI, Basel, Switzerland. This article is an open access article distributed under the terms and conditions of the Creative Commons Attribution (CC BY) license (http://creativecommons.org/licenses/by/4.0/). 